\title{
Night Spraying Peanut Fungicides II. Application Timings and Spray Deposition in the Lower Canopy
}

\author{
J. Augusto, T. B. Brenneman, and A. K. Culbreath, Department of Plant Pathology, and P. Sumner, Department of \\ Biological and Agricultural Engineering, University of Georgia Coastal Plain Experiment Station, Tifton 31793
}

\begin{abstract}
Augusto, J., Brenneman, T. B., Culbreath, A. K., and Sumner, P. 2010. Night spraying peanut fungicides II. Application timings and spray deposition in the lower canopy. Plant Dis. 94:683689.

Chemical control of soilborne peanut (Arachis hypogaea) diseases requires deposition of fungicide on plant tissues near the soil. Four applications of a protectant fungicide, chlorothalonil (1.26 kg a.i./ha), or a systemic, azoxystrobin ( $0.21 \mathrm{~kg}$ a.i./ha), pyraclostrobin $(0.21 \mathrm{~kg}$ a.i./ha), or prothioconazole $(0.08 \mathrm{~kg}$ a.i./ha) plus tebuconazole $(0.15 \mathrm{~kg}$ a.i./ha), were sprayed either (i) early in the morning (3:00 to 5:00 A.M., with folded and wet leaves), (ii) during daylight (10:00 A.M. to 12:00 P.M., with unfolded and dry leaves), or (iii) in the evening (9:00 to 10:00 P.M., with folded and dry leaves). All timings of systemic fungicides provided similar control of foliar diseases. Early-morning applications of pyraclostrobin and prothioconazole plus tebuconazole decreased stem rot (caused by Sclerotium rolfsii) at digging compared with day and evening applications. All systemic fungicides increased yield when applied at early-morning compared with day applications. Spray coverage, density, and droplet size were higher with night than day applications, and differences were more evident in the lower canopy layers. These results suggest that applications made early in the morning to folded, wet leaves can improve spray penetration of peanut canopies, thus improving stem rot control and increasing yield.
\end{abstract}

Stem rot (caused by Sclerotium rolfsii Sacc.) was the most important disease in peanut in Georgia for the 2006 and 2007 growing seasons $(20,21)$. Although the disease is more prevalent in wet seasons $(2,14,15)$, severe outbreaks may occur in dry seasons as well (40). Crop rotations have been shown to decrease stem rot in peanut $(19,29,30,35)$, and growers are discouraged from planting peanut in the same field more often than once every 3 years (22). Rotations with grass crops are particularly beneficial (22). However, most growers still rely on some level of fungicide inputs to control stem rot, and all commercial peanut crops are sprayed to control leaf spots caused by Cercospora arachidicola or Cercosporidium personatum (28). These fungicides are typically initiated 30 to 40 days after planting (DAP) when the plants are smaller; however, the canopy rapidly develops a thick layer of overlapping leaves. The fungicides are applied over the top of the peanut canopy by either aerial or ground sprays. However, with dense peanut foliage, fungicide penetration to the bottom of the canopy to target stem rot is difficult. Ap-

Corresponding author: J. Augusto

E-mail: jaugusto@uga.edu

Accepted for publication 22 January 2010.

doi:10.1094/PDIS-94-6-0683

(c) 2010 The American Phytopathological Society plication techniques to improve fungicide penetration and deposition to control $S$. rolfsii have been reported in peanut $(3,17)$, as well as in great northern bean (11) and carrot (25) for control of Sclerotinia spp. $(4,7,9)$. In peanut, these techniques involved either modification of the sprayer to open the canopy or application of the fungicide following pruning of the vines. Most of these techniques did not consistently improve disease control or increase pod yield.

Although peanut foliage is hard to penetrate during the day when fungicides are typically applied, the leaves fold up at night, resulting in very different canopy architecture. Leaf folding and other movements, known as nyctinastic movements (39), are common in plants with compound leaves, as in the family Leguminosae. At sunset, in response to light-todark transitions, the spatial configuration of the leaf lamina changes from an expanded to a compactly folded architecture. These leaf movements are reversed by a photonastic unfolding that takes place at sunrise in response to the opposite, darkto-light transition (23). The biological processes involved in leaf movements in plants have been extensively described $(32,33,37,38)$. In part I of this article series, night (3 to 5:00 A.M.) applications of azoxystrobin $(0.31 \mathrm{~kg}$ a.i./ha, two applications) and tebuconazole $(0.21 \mathrm{~kg}$ a.i./ha, four applications), applied when peanut leaves were folded, decreased stem rot incidence and increased pod yield com- pared with day applications of the same fungicides when leaves were unfolded (1). That study also documented improved fungicide residual activity on shaded bottom leaves (on which fungicides would be better deposited with night application) compared with top, sun-exposed leaves (where most fungicide would be deposited with a day application). This helps explain the improved fungicide efficacy on stem rot control with the night applications but there may be other mechanisms as well. For example, the effect of applying treatments to wet foliage in the early morning is not known.

The first objective of this study was to compare fungicide application timings for the control of stem rot, leaf spots, and peanut pod yield. This combination of treatments allowed evaluation of the relative contributions of dew and foliage architecture to disease control and peanut pod yield with different fungicides. The second objective was to document spray coverage, droplet size, and spray density for night and day applications in the top, middle, and bottom peanut canopy layers at 60, 90, and 120 DAP, as vegetative growth progressed, to compare spray deposition.

\section{MATERIALS AND METHODS}

Fungicide application timing experiments. Two field experiments were conducted at the University of Georgia Coastal Plain Experiment Station Blackshank (latitude: $\mathrm{N} 31^{\circ} 30.113^{\prime}$ and longitude: W083 ${ }^{\circ}$ 32.801') and Lang (latitude: N31 ${ }^{\circ} 30.642^{\prime}$

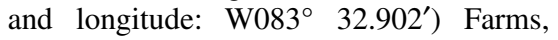
Tifton, GA, in 2008 to evaluate earlymorning, evening, and day fungicide applications for the control of stem rot and leaf spots and benefits on peanut pod yield. The fields had been under continuous peanut cultivation with a history of $S$. rolfsii infestation and prevalent stem rot. The peanut cv. Georgia Green (5) was planted in all the experiments with seeding rate of 23 seeds/m in a Tifton loamy sand with a $\mathrm{pH}$ of 6.0. The planting dates were 6 May at Blackshank and 7 May at the Lang Farm, and all plots were two-row beds, $7.62 \mathrm{~m}$ long and $1.83 \mathrm{~m}$ wide, with the spacing between rows being $0.91 \mathrm{~m}$. The replications were balanced blocks separated by $2.4-\mathrm{m}$ fallow alleys.

The experiments were designed as split plots with four replications at both locations. The whole-plot treatments were fungicides with four applications of (i) 
chlorothalonil (1.26 kg a.i./ha, Bravo WeatherStik; Syngenta Crop Protection Inc., Greensboro, NC), (ii) pyraclostrobin (0.21 kg a.i./ha, Headline 2.09EC; BASF Corp., Research Triangle Park, NC), (iii) azoxystrobin $(0.21 \mathrm{~kg}$ a.i./ha, Abound 2.08 F; Syngenta Crop Protection, Inc.), (iv) prothioconazole $(0.08 \mathrm{~kg}$ a.i./ha) plus tebuconazole (0.15 kg a.i./ha) (Provost 433 Park, NC), and (v) a nonsprayed control. timings, specifically (i) early in the morning (3:00 to 5:00 A.M.), when leaves were folded and wet; (ii) during the day (10:00 A.M. to 12:00 P.M.) on unfolded and dried leaves; or (iii) in the evening (9:00 to 10:00 P.M.), when leaves were folded but dry. The comparison of applications to dry and wet foliage in the evening and early morning, respectively, was designed to evaluate the impact of dew on fungicide relocation within canopies for disease control.

Fungicide applications for all spray program treatments were initiated 30 to 40 DAP and the subsequent applications followed a 14-day application schedule for a total of seven applications ending about 2 weeks prior to digging and inverting. Apchlorothalonil (1.26 kg a.i./ha, Bravo SC; Bayer CropScience, Research Triangle The subplot treatments were application plications 1,2 , and 7 were cover sprays of

WeatherStik) applied during the day with a conventional tractor-mounted sprayer at about $345 \mathrm{kPa}$ using three $\mathrm{D}_{2-13}$ nozzles per row. Specific treatments in the trial were sprayed at applications 3 to 6 with a $\mathrm{CO}_{2}$-pressurized belt-pack sprayer equipped with a broadcast boom set up to apply 187 liters/ha at $276 \mathrm{kPa}$ traveling 4 $\mathrm{km} / \mathrm{h}$. The spray was applied with three Conejet TX-SS6 hollow-cone nozzles (Spraying Systems Co., Wheaton, IL) per row positioned about $0.3 \mathrm{~m}$ above the top of the peanut canopy. All plots were established and maintained under uniform standard production practices, including irrigation, with the exception of experimental treatments.

Early leaf spot assessment. Early leaf spot (caused by Cercospora arachidicola Hori) was visually assessed at 120 DAP in both locations using the Florida 1-to-10 intensity scale (10), described in detail in part I of this series (1). Leaf spot estimate of a plot was an arithmetic mean of the individual visual assessment values of all plants. As a result of the averaging process of all plants in a plot, the leaf spot intensity rating is a (pseudo-)continuous variable, although it is a discrete variable at the level of the individual plant (26).

Stem rot assessment. Stem rot was assessed by counting the number of stem rot

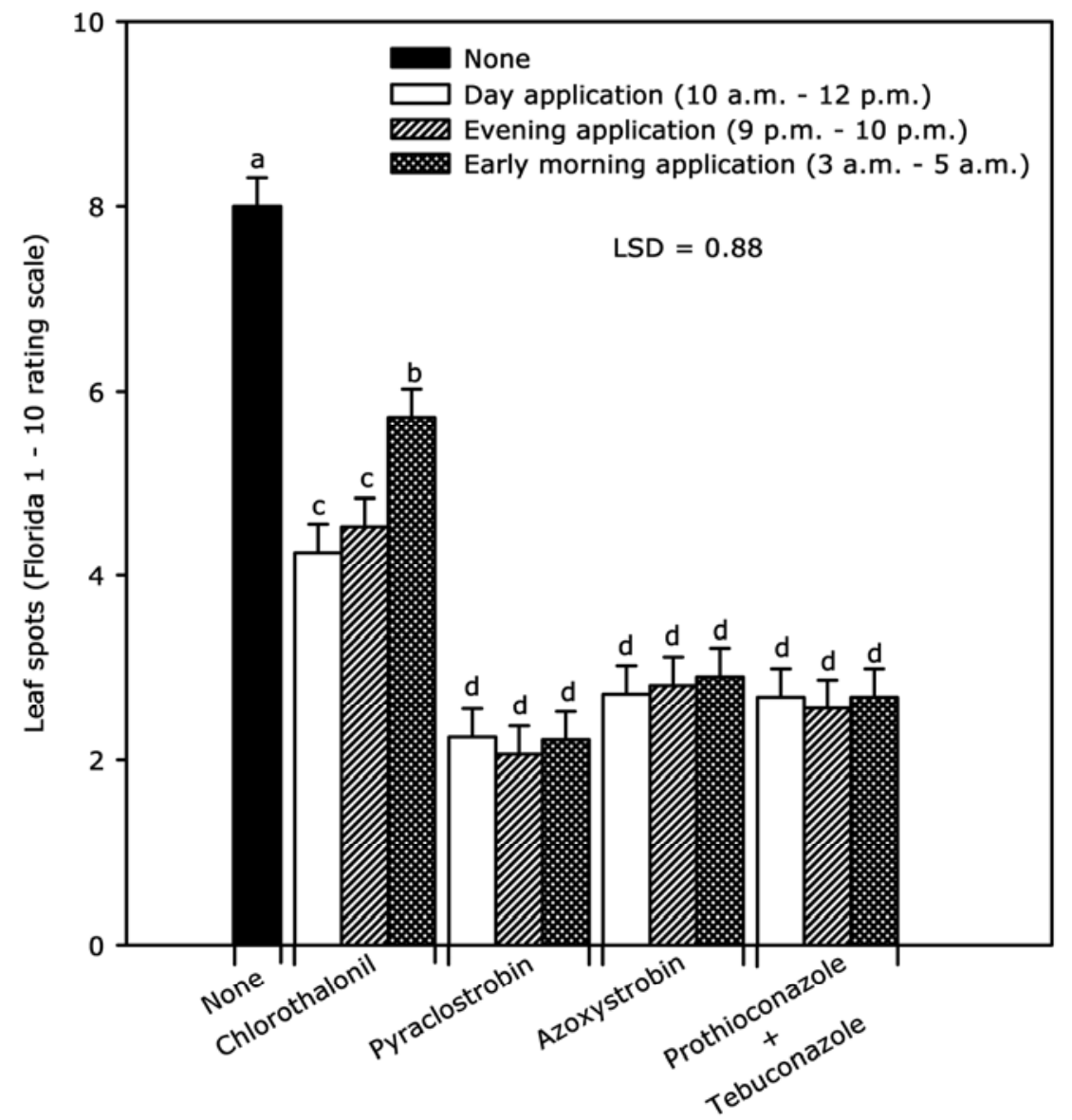

Fig. 1. Effect of fungicide and spray timings on early leaf spot of peanut at Lang and Blackshank Farms, Tifton, GA in 2008. Bar heights are means for spray timings, and bars with different letters are significantly $(P \leq 0.05)$ different according to Fisher's protected least significant difference (LSD). foci in each plot 2 weeks prior to digging and immediately after digging and inverting, when effects of the disease were most evident. A stem rot focus consisted of one or more consecutive affected plants in a $30-\mathrm{cm}$ section of row. Foci counts included only plants with wilted or dead stems with white $S$. rolfsii mycelium or light to darkbrown sclerotia on the plant tissues near or on the soil surface. Stem rot incidence for each plot was then calculated using the formula $\%$ stem rot $=[($ no. of $30-\mathrm{cm} \mathrm{sec}-$ tions affected $) /($ no. of $30-\mathrm{cm}$ total sections in the plot) $] \times 100$.

Pod yield assessment. Adjoining border plots in each field were used to assess maturity of peanut according to the hullscrape maturity method (42). Plots were mechanically dug and inverted with a KMC digger/inverter (Kelly Manufacturing Co., Tifton, GA) at physiological maturity (139 and 125 DAP at the Blackshank and Lang Farms, respectively). Windrows were mechanically harvested with a tworow combine approximately 5 days after digging and inverting. Weight of pods was recorded after soil and foreign materials were removed and they were air dried to about $9 \%$ moisture (wt/wt).

Statistical analysis of fungicide application timing data. Disease assessments and pod yield were subject to analysis of variance using the mixed procedure of SAS (version 9.1; SAS Institute, Cary, NC) to determine significant differences $(P \leq$ $0.05)$ among treatments. Analysis of variance for leaf spots, stem rot, and pod yield was performed with data arranged in a split-plot design nested within locations. Location-treatment interactions for the variables were assessed to determine whether data could be pooled across locations, and means were separated by Fisher's protected least significant difference $(P=0.05)$.

Spray deposition experiments. Two experiments were set up in 2007 in a repeated-measures design to compare night and day applications on spray coverage, spray density, and volume median diameter $\left(\mathrm{VMD}_{0.5}\right)$ within three canopy layers at three different stages of peanut growth. The VMD expresses spray droplet size (in micrometers) and it is a value where $50 \%$ of the total volume of liquid sprayed is made up of droplets with diameters larger than the median value and $50 \%$ smaller than the median value (34). Cv. Georgia Green was planted on 11 May and 16 May at Blackshank (latitude: N31 $30.049^{\prime}$ and longitude: W083 $32.794^{\prime}$ ) and Lang (latitude: $\mathrm{N} 31^{\circ} 30.624^{\prime}$ and longitude: W083 ${ }^{\circ}$ $32.842^{\prime}$ ) Tifton Farms, respectively. The group factor was application timings (night and day) in a randomized complete block design and replicated seven times. Each plot had four white Kromekote (SMART Papers, Hamilton, $\mathrm{OH}$ ) cards (7.6 by 5.1 $\mathrm{cm})$ positioned in each top, middle, and bottom peanut canopy layer. The actual 
width of these layers was relative to the total depth of the canopy and, therefore, varied between locations and time of the season. Repeated measures were sampling dates at 60, 90, and $120 \mathrm{DAP}$, as peanut vegetative growth progressed. All field conditions and management practices were as described previously. No fungicides were applied except for the cover spray with chlorothalonil (1.26 kg a.i./ha) to reduce defoliation by leaf spots. To obtain deposition data, the plots were sprayed with a nonfungicidal solution consisting of a Hi-Light Red tracer dye (Becker Underwood, Inc., Ames, IA) mixed at 0.946 liters per 379 liters of water (approximately 1:400 [vol/vol]). The sprayer was a $\mathrm{CO}_{2}$-pressurized beltpack as described previously. The plots were sprayed at night (3:00 to 5:00 A.M.) or after daybreak (10:00 A.M. to 12:00 P.M.) on the same day. The Kromekote cards were allowed to dry to touch and collected. The cards were then analyzed with DropletScan software (WRK of Oklahoma, Stillwater, OK), which uses a flatbed scanner to allow the measurement of droplets (number, size, and coverage) on sensitive papers $(34,41)$. The scanner resolution was $30 \mu \mathrm{m} / \mathrm{pixel}$.

Statistical analyses of repeatedmeasures spray deposition data. Modeling the covariance structure was the preliminary step in the analysis using the mixed procedure of SAS (version 9.1). Covariance structure of the data was defined by invoking the REPEATED statement. The MODEL statement included application timing, sampling date, and application timing-sampling date interaction. The REPEATED statement included sampling date; canopy layer (by application timing) for the "subject" option; and un (unstructured model) or cs (compound symmetry model) for the "type" option, which was used to determine the covariance structure. The unstructured model was chosen for further data analysis because it minimized the Akaike's information criterion (AIC), AIC corrected (AICC), and Bayesian information criterion (BIC) and provided the best fit for data analysis compared with the compound symmetry model according to the goodness of fit of the covariance structure displayed by "fit statistics" outputs of the two models. The treatment and sampling date effects were assessed using the generalized least-squares means.

\section{RESULTS}

Fungicide application timing experiments. The interaction of locationtreatment was not significant for all measured variables but the fungicideapplication timing interaction was significant for stem rot prior to digging $(P=$ $0.019)$ and at digging $(P=0.027)$ and peanut pod yield $(P=0.038)$. Thus, the data from the two locations were combined but the individual fungicide programs are presented separately.
Early leaf spot ratings at 120 DAP indicated high disease severity in nonsprayed control plots (Fig. 1). The early-morning application of the protectant chlorothalonil fungicide had a significantly $(P=0.047)$ higher rating than the evening or day applications with this fungicide but disease control was still commercially acceptable. Day and evening applications had similar leaf spot ratings with chlorothalonil. Application timings of systemic fungicide pyraclostrobin, azoxystrobin, or prothioconazole plus tebuconazole did not affect levels of leaf spot control and leaf spot ratings were lower than with the chlorothalonil treatments (Fig. 1).

The early-morning application of pyraclostrobin significantly $(P=0.001)$ decreased aboveground stem rot incidence recorded 2 weeks prior to digging compared with the day and evening application of the same fungicide (Fig. 2). The other two systemic fungicides, azoxystrobin and prothioconazole plus tebuconazole, did not show significant differences among application timings in aboveground stem rot prior to digging. As expected, application timings with chlorothalonil had no effect on aboveground stem rot incidence (Fig. 2).

Pyraclostrobin and prothioconazole plus tebuconazole had significantly $(P=0.001$ and 0.029 , respectively) lower stem rot at digging with early-morning applications than day and evening (pyraclostrobin) applications (Fig. 3). Stem rot incidence at digging was not significantly different between evening and day applications of pyraclostrobin or prothioconazole plus tebuconazole. Azoxystrobin did not show significant differences $(P=0.072)$ in stem rot incidence at digging among application timings. However, all application timings with azoxystrobin had similar levels of stem rot control at digging compared with early-morning application of pyraclostrobin and evening and early-morning applications of prothioconazole plus tebuconazole (Fig. 3). Application timings with chlorothalonil had no effect on stem rot and disease incidence was similar to the nonsprayed control plots.

There were significant differences among application timings in peanut pod yield for pyraclostrobin $(P=0.029)$, azoxystrobin $(P=0.031)$, or prothioconazole plus tebuconazole $(P=0.019)$. Earlymorning applications of pyraclostrobin resulted in higher pod yield than day and evening applications of the same fungicide (Fig. 4). Early-morning applications of azoxystrobin resulted in higher pod yield than day applications, while early-morning and evening applications of prothioconazole plus tebuconazole increased pod yield compared with day applications. Earlymorning and evening applications of azoxystrobin and prothioconazole plus tebuconazole had similar pod yields but early-

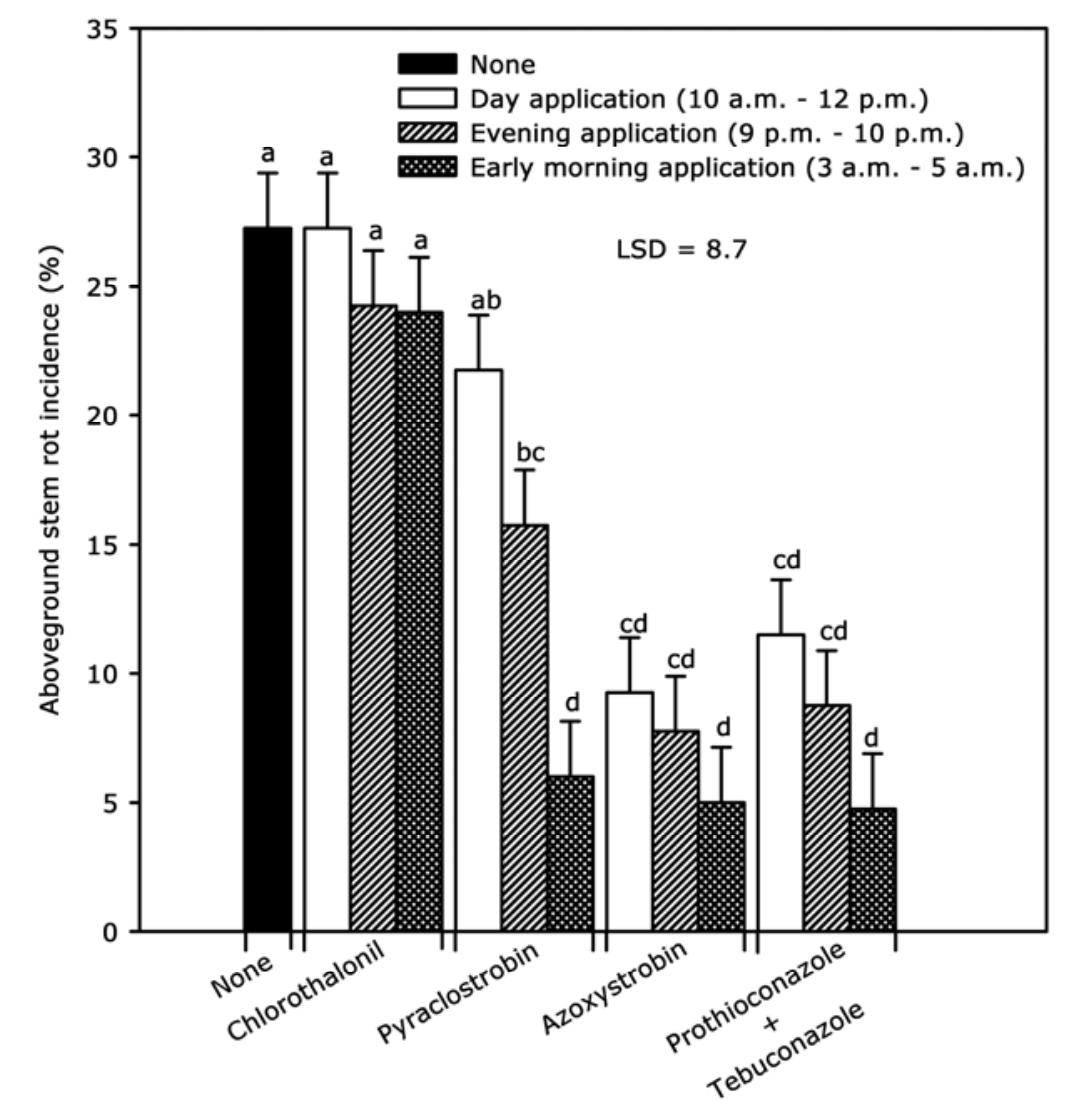

Fig. 2. Effect of fungicide and spray timings on aboveground stem rot incidence in peanut at Lang and Blackshank Farms, Tifton, GA in 2008. Bar heights are means for spray timings, and bars with different letters are significantly $(P \leq 0.05)$ different according to Fisher's protected least significant difference (LSD). 


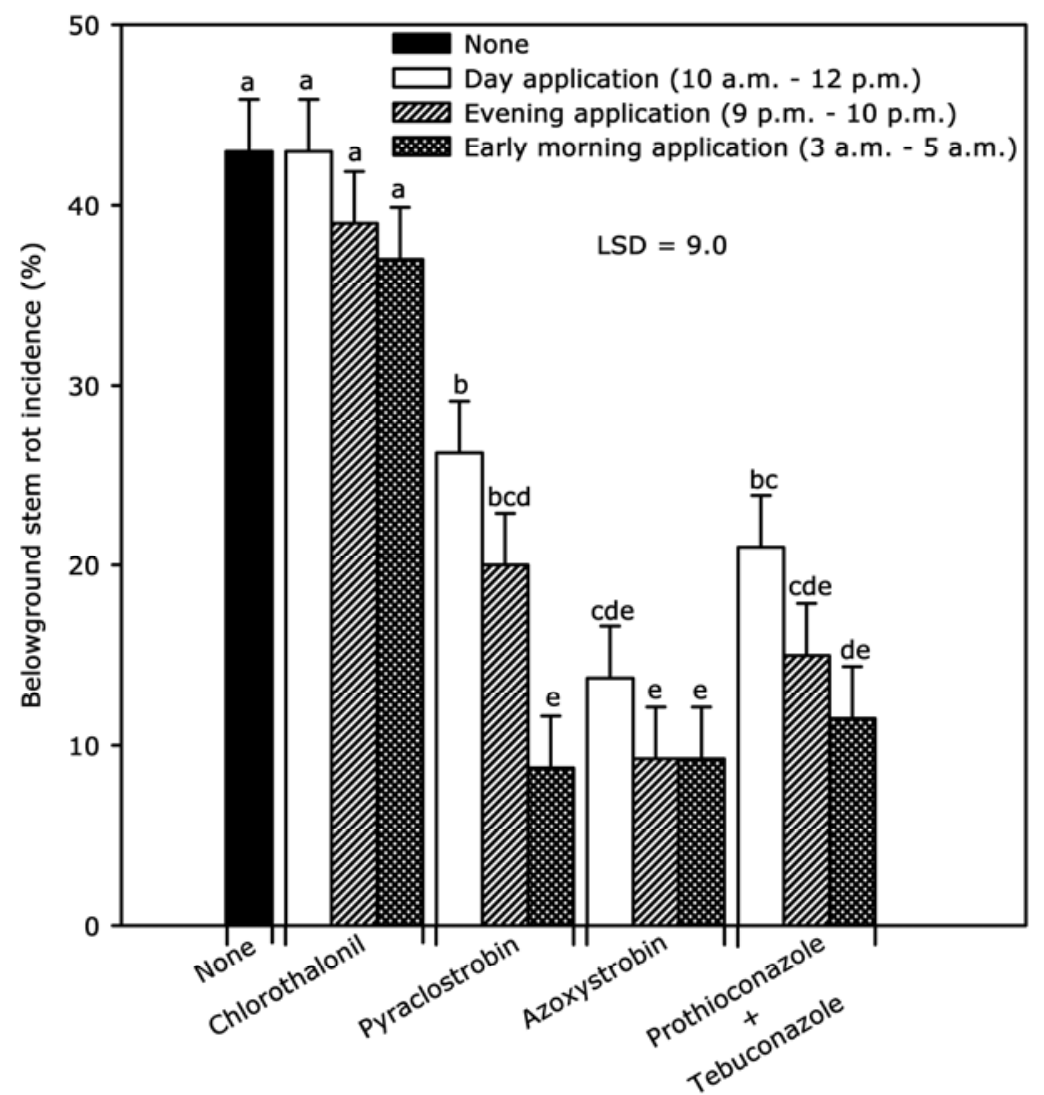

Fig. 3. Effect of fungicide and spray timings on belowground stem rot incidence in peanut at Lang and Blackshank Farms, Tifton, GA in 2008. Bar heights are means for spray timings, and bars with different letters are significantly $(P \leq 0.05)$ different according to Fisher's protected least significant difference (LSD).

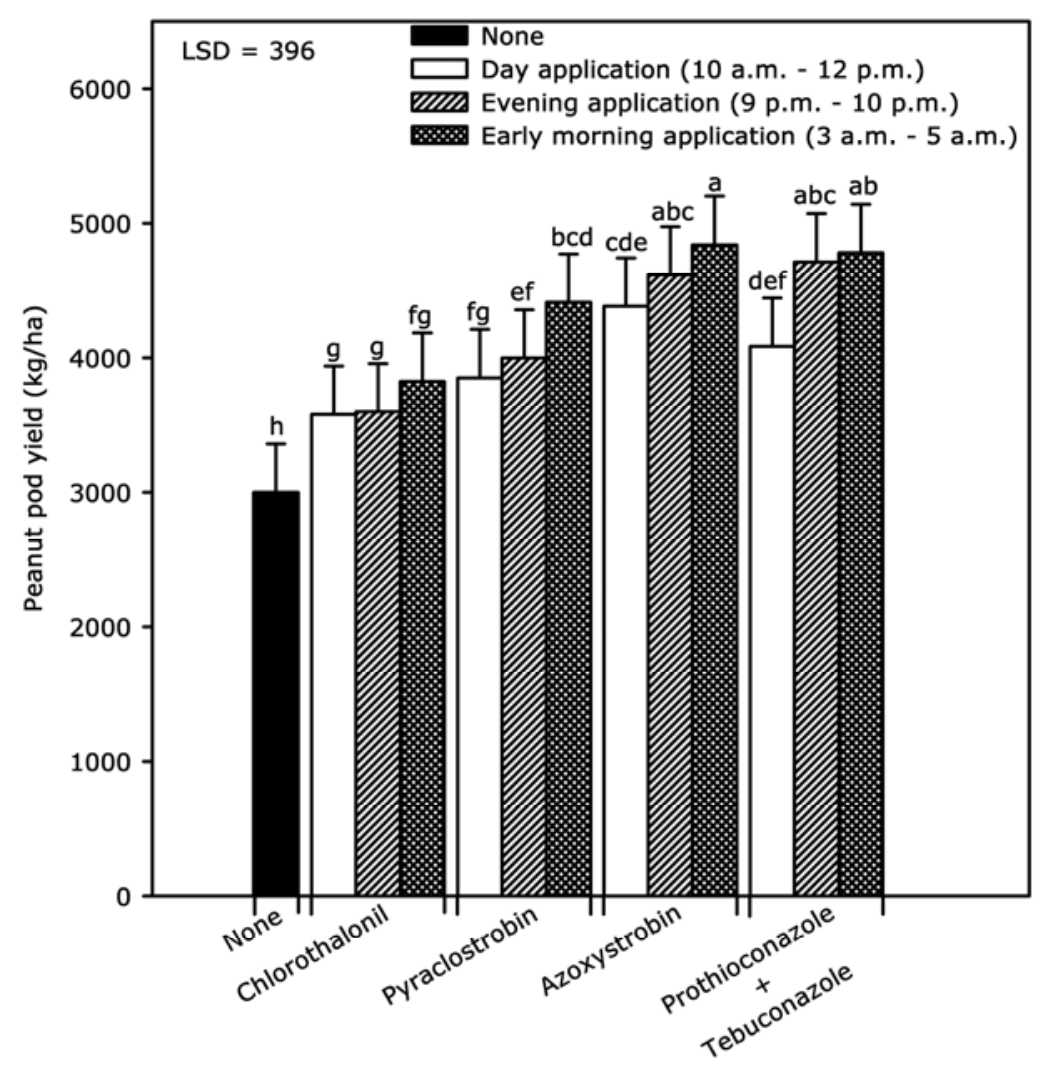

Fig. 4. Effect of fungicide and spray timings on peanut pod yield at Lang and Blackshank Farms, Tifton, GA in 2008. Bar heights are means for spray timings, and bars with different letters are significantly $(P \leq 0.05)$ different according to Fisher's protected least significant difference (LSD). morning application of pyraclostrobin was only similar in pod yield to day and evening applications of the other two systemic fungicides (Fig. 4).

Spray deposition. Data analysis showed significant treatment-sampling date interaction for spray coverage, spray density, and spray droplet size $(P=0.013$, 0.017 , and 0.006 , respectively). However, there was no significant location-treatment interaction for the three measured parameters. Data were pooled across locations but the results are presented separately for each sampling date. The combined results showed decreasing average spray coverage from top to middle to bottom canopy layers at 60,90, and 120 DAP with both night and day applications (Fig. 5). Overall spray coverage in the top, middle, and bottom canopy layers decreased as the season progressed for both night and day applications. Spray coverage was similar for night and day applications at top, middle, and bottom canopies at 60 DAP. However, night applications showed increased spray coverage in each canopy layer 90 and 120 DAP compared with the day applications (Fig. 5). For example, night applications in the middle canopy had similar coverage with day applications in the top canopy at 90 and 120 DAP. Night applications in the bottom canopy and day applications in the middle canopy had similar coverage at 90 DAP but differences were more dramatic at $120 \mathrm{DAP}$, where night applications in the bottom canopy had significantly higher coverage than day applications in the bottom canopy $(P<$ $0.001)$ and even higher than day applications in the middle canopy $(P=0.001)$ (Fig. 5).

Spray density for night and day applications decreased from the top to middle to bottom canopy layer at 60, 90, and 120 DAP (Fig. 6). At 60 DAP, only the middle and bottom canopies had significantly $(P<$ 0.001 ) higher spray densities from night than from day applications. However, as peanut vegetative growth increased, spray density was always higher for night than day applications regardless of canopy at 90 and 120 DAP (Fig. 6).

The droplet size decreased from the top to middle to bottom canopies but night applications had increased spray droplet sizes compared with the day applications in all the sampling dates (Fig. 7).

\section{DISCUSSION}

The presence of dew at early morning when the protectant chlorothalonil fungicide was applied significantly $(P=0.047)$ decreased early leaf spot control compared with the evening or day applications applied to dry foliage. Infection and sporulation by $C$. arachidicola, the most important leaf spot pathogen in most of Georgia in recent years (13), occurs on the upper leaf surface, whereas most of the fungicide applied early in the morning, when peanut 
leaves are folded, is deposited on the lower leaf surface (our personal observation). The fungicides used in this study, other than chlorothalonil, have some degree of systemic movement via either translaminar or apoplastic movement, and they provided similar levels of early leaf spot control for all application timings.

The efficacy of pyraclostrobin on stem rot was improved by the presence of dew during early-morning applications more than any of the other systemic fungicides. Pyraclostrobin is attracted to waxes on and within the leaf cuticle and will rapidly bind when applied to dry foliage (24), thus resulting in decreased redistribution on the lower canopy and, therefore, erratic control of stem rot. The dew in the morning may serve to prevent initial binding, and also relocate the fungicide by physically washing it off the leaf to the lower foliage, where $S$. rolfsii infection occurs. Water applied to peanut plants has been shown to very effectively move chemicals from

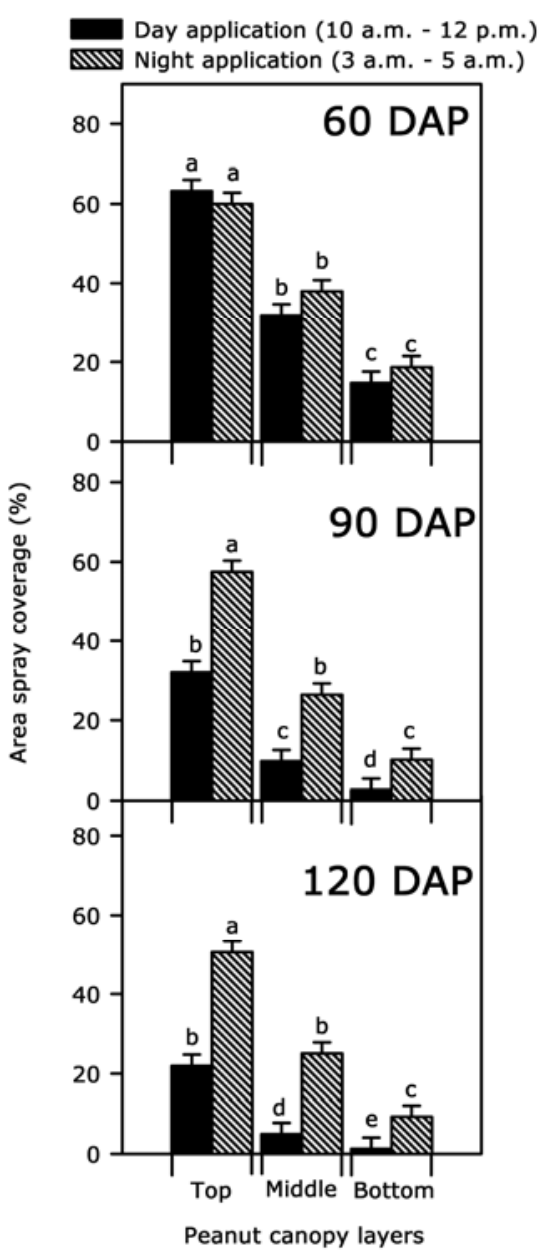

Fig. 5. Evaluation of peanut canopy, spray timings, and sampling dates on percent spray coverage across two locations in Tifton, GA in 2007. Spray coverage bars with the same letter within or among canopy layers, and regardless of sampling dates, are not significantly different $(P=0.05)$. Sampling dates were at 60 days after planting (DAP) (23-cm-tall peanut plants), 90 DAP (28-cm-tall peanut plants), and 120 DAP (33-cm-tall peanut plants). leaves to the lower stems, pegs, and even the soil, where they are needed to control soilborne pathogens (12). The other systemic fungicides in this study showed a similar trend but not to the same magnitude as pyraclostrobin, and this may be related to their relative binding affinity to the leaf cuticle.

Fungicide performance against stem rot in peanut has previously been associated with adequate redistribution in the canopy by irrigation (43) or improving initial deposition by modifying the peanut canopy by pruning (3) or use of a canopy opener when spraying (17). In Georgia, only $55 \%$ of peanut acreage receives some irrigation $(20,21)$, and the remaining fields are reliant upon rainfall. Although at least one study in soybean also showed that a spray canopy opener could provide higher spray coverage and density in the middle and bottom canopies than the conventional sprayers (27), neither the modification of the sprayer to open the canopy nor the

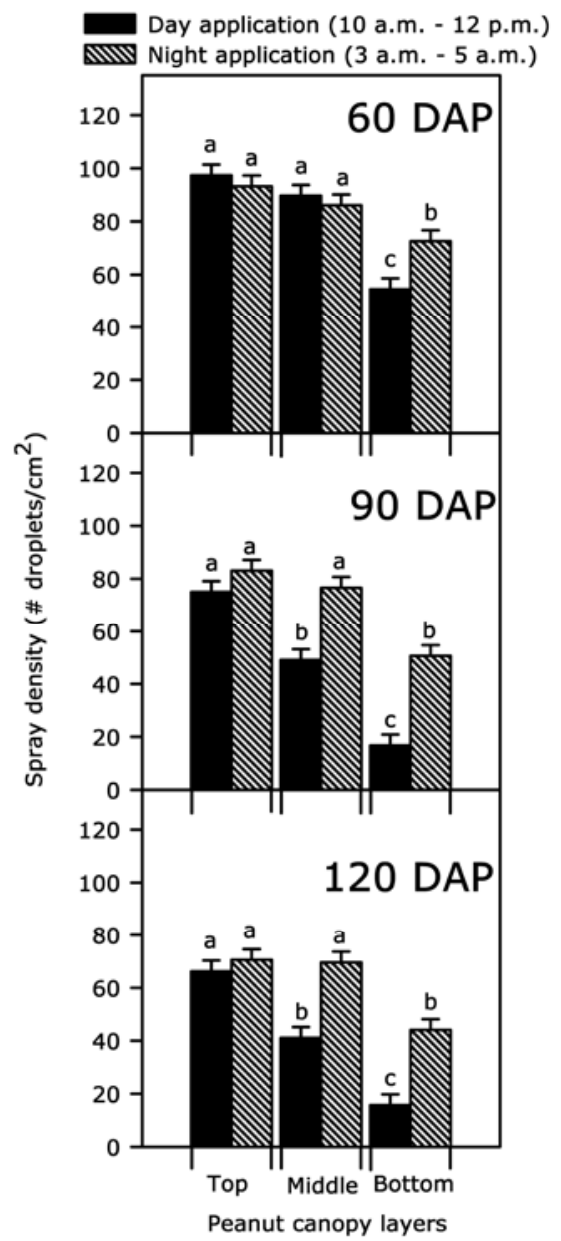

Fig. 6. Evaluation of peanut canopy, spray timings, and sampling dates on spray density across two locations in Tifton, GA in 2007. Spray density bars with the same letter within or among canopy layers, and regardless of sampling dates, are not significantly different $(P=$ 0.05). Sampling dates were at 60 days after planting (DAP) (23-cm-tall peanut plants), 90 DAP (28-cm-tall peanut plants), and 120 DAP (33-cm-tall peanut plants). application of fungicide following pruning of the vines has been practical or consistently improved disease control in peanut. In addition, pruning the foliage can significantly reduce peanut pod yields $(31,36)$.

Improved stem rot control and increased peanut yields with night application, when leaves are folded, may partially result from increased spray deposition in the lower canopy. In these experiments, spray coverage and density of spray droplets in the lower canopy were always higher with night applications compared with day applications, especially as peanut growth progressed. This increase in spray penetration of the canopy with night applications is probably most attributable to the sparse canopy at night (when leaves are folded) compared with the thick canopy during the day (when leaves are unfolded). Nevertheless, the increase in spray deposition with night applications may also be due to re-

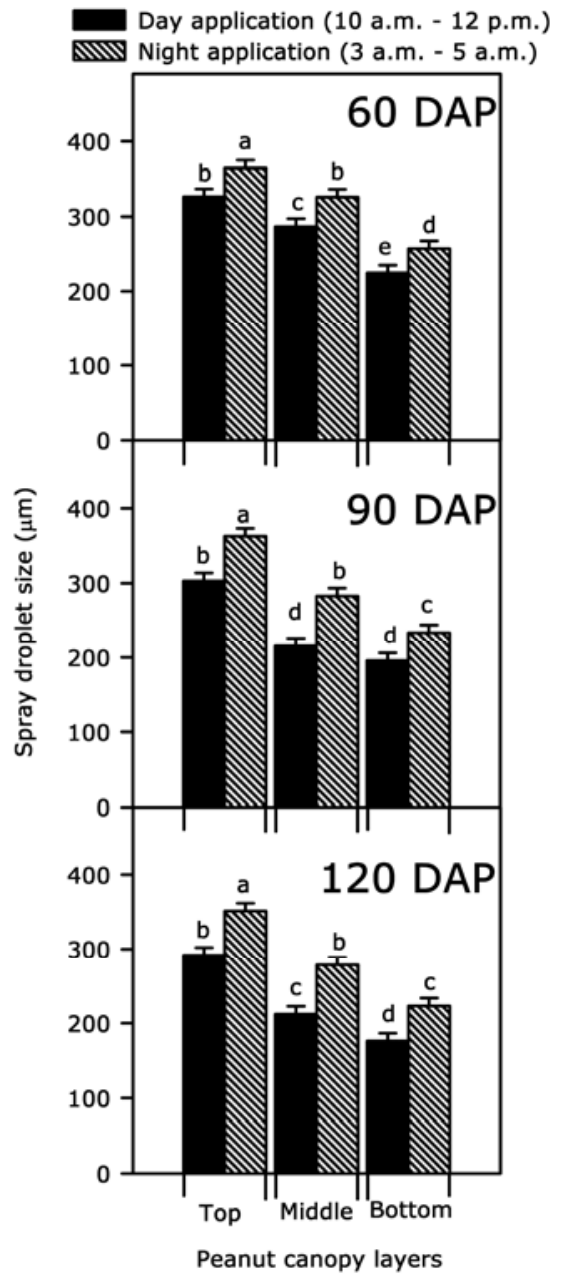

Fig. 7. Evaluation of peanut canopy, spray timings, and sampling dates on droplet size (volume median diameter) across two locations in Tifton, GA in 2007. Droplet size bars with the same letter within or among canopy layers, and regardless of sampling dates, are not significantly different $(P=$ $0.05)$. Sampling dates were at 60 days after planting (DAP) (23-cm-tall peanut plants), 90 DAP (28-cm-tall peanut plants), and 120 DAP (33-cmtall peanut plants). 
duced spray drift and droplet evaporation at night compared with daylight applications, and spray droplet size was found to be larger in all three canopy layers with the night versus day sprays. Increased spray penetration of the canopy was most evident later in the season, and our results showed that spray coverage was at least doubled within all canopy layers with night compared with day sprays at 120 DAP. Other experiments in peanut, soybean, and potato with day fungicide applications found decreased spray coverage in the lower versus the upper canopies that was also more pronounced with increasing plant growth $(6,16,18,44)$.

The spray coverage and density as well as droplet size required for effective disease control depend on the crop and disease, as well as the specific fungicide. Tall crops with dense foliage may require larger droplet sizes for adequate spray penetration into lower canopies. Foliar diseases may require smaller droplet sizes and higher coverage than soilborne diseases, especially with protectant fungicides like chlorothalonil. In soybean, where infection by Asian soybean rust begins in the lower canopy and leaves stay wet for longer periods, the lower soybean canopy is the primary spray target. Spray coverage as dense as 62 droplets $/ \mathrm{cm}^{2}$ with mediumfine droplets of $220 \mu \mathrm{m}$ or less are considered effective for soybean rust control with ground-applied fungicides (8). Our results showed that night sprays almost always had droplet sizes larger than these droplet sizes in soybean. These larger droplets are better suited to penetrate the canopy but apparently still provided adequate coverage, especially because the droplet density was increased. The one exception was leaf spot control with the protectant fungicide chlorothalonil, where night applications were less effective. However, this was probably due to the effects of water on the leaves because the evening applications were just as effective as the day applications.

The results reported here are in line with findings discussed in part I of this article series, in which night fungicide applications with folded leaves increased control of stem rot and extended residual activity of fungicides (1). Apparently, increased spray coverage, density, and droplet size, especially within the bottom plant canopy where $S$. rolfsii infection occurs, also contribute to improved disease control and pod yield with night applications. These data further show that maximum benefit is obtained from sprays applied early in the morning, before daylight. The concept of spraying at night makes intuitive sense to growers and they have been quick to adopt this new practice. Crop advisers and growers are conducting on-farm trials to validate the principle as well. Some trials in well-rotated fields with low disease pressure have had no or only small differences in disease control and pod yield. However, trials with more severe stem rot have shown significant yield advantages to night spraying, and no trial had lower yield from night spraying versus day applications. It is of interest to note that, in this study, morning applications of azoxystrobin increased yield significantly compared with day applications even when no difference in disease control was observed. This presumably was due to improved control of some secondary diseases such as Rhizoctonia limb rot (Rhizoctonia solani AG-4), which also occur in the bottom part of the plant canopy and which are more difficult to evaluate, particularly when they only damage the peanut pegs.

The potential economic benefits of this practice are obvious, especially because implementation involves no capital investment or equipment modification. In some cases, there may be minimal additional labor cost. However, for growers who do not have enough equipment for the land area they farm, night applications help them further utilize the sprayers they already own. This research will help peanut farmers manage soilborne pathogens more effectively and improve our understanding of the relationship between fungicide chemistry, deposition patterns, and disease control.

\section{ACKNOWLEDGMENTS}

Funding for this research was provided in part by the Georgia Peanut Commission and the Nicaraguan Peanut Growers Association. We thank P. Hilton, L. Mullis, R. Griffin, and A. Graham for their field and laboratory assistance.

\section{LITERATURE CITED}

1. Augusto, J., Brenneman, T. B., Culbreath, A. K., and Sumner, P. 2010. Night spraying peanut fungicides I. Extended fungicide residual and improved stem rot control. Plant Dis. 94:000-000.

2. Backman, P. A. 1984. Stem rot. Pages 15-16 in: Compendium of Peanut Diseases. D. M. Porter, D. H. Smith, and R. Rodriguez-Kabana, eds. American Phytopathological Society, St. Paul, MN.

3. Backman, P. A., Rodriguez-Kabana, R., and Williams, J. C. 1975. The effect of peanut leafspot fungicides on the nontarget pathogen, Sclerotium rolfsii. Phytopathology 65:773-776.

4. Bailey, J. E., and Brune, P. D. 1997. Effect of crop pruning on Sclerotinia blight of peanut. Plant Dis. 81:990-995.

5. Branch, W. D. 1996. Registration of 'Georgia Green' peanut. Crop Sci. 36:806.

6. Bruhn, J. A., and Fry, W. E. 1982. A statistical model of fungicide deposition on potato foliage. Phytopathology 72:1301-1305.

7. Brune, P. D., and Bailey, J. E. 1992. Modification of canopy microclimate by pruning to control Sclerotinia blight of peanut. (Abstr.) 1992 Proc. Am. Peanut Res. Educ. Soc. 24:42.

8. Butzen, S., Marcon, A., McInnes, B., and Schuh, W. 2005. Asian soybean rust: fungicide application technology. Crop Insights, Vol. 5, no. 1. Pioneer Hi-Bred. Johnston, IA.

9. Butzler, T. M., Bailey, J., and Beute, M. K. 1998. Integrated management of Sclerotinia blight in peanut: utilizing canopy morphology, mechanical pruning, and fungicide timing. Plant Dis. 82:1312-1318.

10. Chiteka, Z. A., Gorbet, D. W., Shokes, F. M.,
Kucharek, T. A., and Knauft, D. A. 1988 Components of resistance to late leaf spots in peanut. I. Levels of variability-implications for selection. Peanut Sci. 15:25-30.

11. Coyne, D. P., Stedman, J. R., and Anderson, F. N. 1974. Effect of modified architecture of great northern dry bean varieties (Phaseolus vulgaris) on white mold severity and components of yield. Plant Dis. Rep. 58:379-382.

12. Csinos, A. S., and Kvein, C. S. 1988. Deposition of sprays on the soil for soilborne targets of peanut. (Abstr.) Proc. Am. Peanut Res. Educ. Soc. 20:34

13. Culbreath, A. K., Brenneman, T. B., and Kemerait, R. C., Jr. 2002. Management of early leaf spot of peanut with pyraclostrobin as affected by rate and spray interval. Plant Health Progress doi:10.1094/PHP-2002-101801-RS.

14. Culbreath, A. K., Minton, N. A., Brenneman, T. B., and Mullinix, B. G. 1992. Response of Florunner and Southern Runner peanut cultivars to chemical management of late leaf spot, southern stem rot, and nematodes. Plant Dis. 76:1199-1203.

15. Davis, R. F., Smith, F. D., Brenneman, T. B., and McLean, H. 1996. Effect of irrigation on expression of stem rot of peanut and comparison of aboveground and belowground disease ratings. Plant Dis. 80:1155-1159.

16. Geary, B., Hamm, P. B., and Johnson, D. A. 2004. Deposition and redistribution of fungicides applied by air and chemigation for control of late blight in commercial potato fields. Am. J. Potato Res. 81:305-315.

17. Grichar, W. J. 1995. Management of stem rot of peanuts (Arachis hypogaea) caused by Sclerotium rolfsii with fungicides. Crop Prot. 14:111-115.

18. Hanna, S. O., Conley, S. P., Shaner, G. E., and Santini, J. B. 2008. Fungicide application timing and row spacing effect on soybean canopy penetration and grain yield. Agron. J. 100:1488-1492.

19. Johnson, A. W., Minton, N. A., Brenneman, T. B., Burton, G. W., Culbreath, A. K., Gascho, G. J., and Baker, S. H. 1999. Bahiagrass, corn, cotton rotations, and pesticides for managing nematodes, diseases, and insects on peanut. J. Nematol. 31:191-200.

20. Kemerait, R. 2006. Georgia plant disease loss estimates. Coop. Ext. Serv. Bull. 41-09, University of Georgia, Athens.

21. Kemerait, R. 2007. Georgia plant disease loss estimates. Coop. Ext. Serv. Bull. 41-10, University of Georgia, Athens.

22. Kemerait, B., Brenneman, T., and Culbreath, A. 2005. Peanut disease update. Pages 24-40 in: 2005 Peanut Update. E. Prostko, ed. Coop. Ext. Serv. Coll. Agric. Environ. Sci. University of Georgia, Athens.

23. Koller, D. 1990. Light-driven leaf movements. Plant Cell Environ. 13:615-632.

24. Martin, B. 2003. A new strobilurin fungicide for turfgrass disease control. Golf Course Manage. 71:188-191.

25. McDonald, M. R., Vander Kooi, K. D., and Westerveld, S. M. 2008. Effect of foliar trimming and fungicides on apothecial number of Sclerotinia sclerotiorum, leaf blight severity, yield, and canopy microclimate in carrot. Plant Dis. 92:132-136.

26. McRoberts, N., Hughes, G., and Madden, L. V. 2003. The theoretical basis and practical application of relationships between different disease intensity measurements in plants. Ann. Appl. Biol. 142:191-211.

27. Ozkan, H. E., Zhu, H., Derksen, R. C., Guler, H., and Krause, C. R. 2006. Evaluation of various spraying equipment for effective application of fungicides to control Asian soybean rust. International Advances in Pesticide Applications 2006, Robinson College, Cambridge, UK. Asp. Appl. Biol. 77:423-431. 
28. Rideout, S. L., Brenneman, T. B., Culbreath, A. K., and Langston, D. B., Jr. 2008. Evaluation of weather-based spray advisories for improved control of peanut stem rot. Plant Dis. 92:392-400.

29. Rodriguez-Kabana, R., Kokalis-Burelle, N., Robertson, D. G., King, P. S., and Wells, L. W. 1994. Rotations with coastal bermudagrass, cotton, and bahiagrass for management of Meloidogyne arenaria and southern blight in peanut. J. Nematol. (Suppl.) 26:665-668.

30. Rodriguez-Kabana, R., Robertson, D. G., Wells, L., Weaver, C. F., and King, P. S. 1991. Cotton as a rotation crop for the management of Meloidogyne arenaria and Sclerotium rolfsii in peanut. J. Nematol. (Suppl.) 23:652-657.

31. Santos, R. B., and Sutton, B. G. 1983. Effect of defoliation on reproductive development of the peanut. Aust. J. Agric. Res. 34:527-535.

32. Satter, R. L., Geballe, G. T., Applewhite, P. B., and Galston, A. W. 1974. Potassium flux and leaf movement in Samanea saman. I. Rhythmic movement. J. Gen. Physiol. 64:413-430.

33. Satter, R. L., Geballe, G. T., and Galston, A.
W. 1974. Potassium flux and leaf movement in Samanea saman. II. Phytochrome controlled movement. J. Gen. Physiol. 64:431-442.

34. Sumner, P. E., Roberts, P. M., and Edwards, R. P. 2007. Comparison of low-drift nozzles for canopy penetration in cotton. ASABE Pap. No. 071152. ASABE, St. Joseph, MI.

35. Timper, P., Minton, N. A., Johnson, A. W., Brenneman, T. B., Culbreath, A. K., Burton, G. W., Baker, S. H., and Gascho, G. J. 2001. Influence of cropping systems on stem rot (Sclerotium rolfsii), Meloidogyne arenaria, and the nematode antagonist Pasteuria penetrans in peanut. Plant Dis. 85:767-772.

36. Turner, J. W. 1982. Effect of defoliation on yield of peanut (Arachis hypogaea). Queensl. J. Agric. Anim. Sci. 39:1983-185.

37. Ueda, M., Nakamura, Y., and Okada, M. 2007. Endogenous factors involved in the regulation of movement and "memory" in plants. Pure Appl. Chem. 79:519-527.

38. Ueda, M., Shigemori, H., Sata, N., and Yamamura, S. 2000. The diversity of chemical substances controlling the nyctinastic leaf- movement in plants. Phytochemistry 53:3944

39. Ueda, M., Takada, N., and Yamamura, S. 2001 Molecular approach to the nyctinastic movement of the plant controlled by a biological clock. Int. J. Mol. Sci. 2:156-164.

40. Watkins, G. M. 1961. Physiology of Scle rotium rolfsii, with emphasis on parasitism. Phytopathology 51:110-113.

41. Whitney, R. W., and Gardisser, D. R. 2003. DropletScan operators manual. WRK of Oklahoma and WRK of Arkansas.

42. Williams, E. J., and Drexler, J. S. 1981. A nondestructive method for determining peanut pod maturity. Peanut Sci. 8:134-141.

43. Woodward, J. E. 2006. Optimizing efficacy and economic benefits of fungicides for peanut disease control via pre-plant analysis of disease risk and irrigation timing. Ph.D. dissertation, University of Georgia, Athens.

44. Zhu, H., Dorner, J. W., Rowland, D. L., Derksen, R. C., and Ozkan, H. E. 2004. Spray penetration into peanut canopies with hydraulic nozzle tips. Biosyst. Eng. 87:275-283. 